Revista de Biología Marina y Oceanografía

Vol. 48, №3: 459-469, diciembre 2013

DOI 10.4067/S0718-19572013000300005

Article

\title{
Relationship between energy allocation and gametogenesis in Aulacomya atra (Bivalvia: Mytilidae) in a sub-Antarctic environment
}

\author{
Relación entre reproducción y asignación de energía en Aulacomya atra \\ (Bivalvia: Mytilidae) en un ambiente sub-antártico \\ Analía F. Pérez ${ }^{1}$ Claudia C. Boy², Jessica Curelovich¹, \\ Patricia Pérez-Barros ${ }^{1}$ and Javier A. Calcagno ${ }^{1}$
}

\begin{abstract}
${ }^{1}$ Consejo Nacional de Investigaciones Científicas y Técnicas (CONICET)-Centro de Estudios Biomédicos, Biotecnológicos, Ambientales y de Diagnóstico, Instituto Superior de Investigaciones, Universidad Maimónides, Hidalgo 775 (1405), Ciudad Autónoma de Buenos Aires, Argentina. analiaperez@conicet.gov.ar

${ }^{2}$ Centro Austral de Investigaciones Científicas (CADIC-CONICET), Bernardo Houssay 200, V9410BFD Ushuaia, Tierra del Fuego, Argentina

Resumen.- Se analizó la gametogénesis y la variación temporal en la asignación de energía a diferentes órganos de Aulacomya atra del Canal Beagle (Tierra del Fuego). El periodo de desove de A. atra se extendió desde el final del invierno hasta la primavera, cuando el MGI (Índice gónada-manto) resultó mínimo y el número de individuos desovados, máximo. En los machos maduros el incremento del MGI coincidió con un descenso en la densidad energética del manto-gónada $\left(E D_{M G}\right)$, lo que está relacionado con un aumento de masa con menor energía. En hembras maduras el incremento de MGI se relaciona con un aumento de masa con valores más altos de energía, que determina el aumento de la $_{E_{\mathrm{MG}}}$. Durante la maduración gonadal existen diferentes estrategias de asignación de energía en ambos sexos, aunque se alcanza similar contenido de energía en el manto-gónada; los machos mantienen gónadas más grandes, pero con menos energía por unidad de masa que las hembras. Además, en los individuos maduros desciende el valor del índice de la glándula digestiva (DGI), incrementa el MGI, y tiende a la depleción de la ED y del contenido energético, sugiriendo que este órgano actuaría como reservorio de energía.
\end{abstract}

Palabras clave: Energética, calorimetría, reproducción, bivalvo, Canal Beagle, Aulacomya atra

\begin{abstract}
Gametogenesis and temporal variation in energy allocation to different organs were analyzed in Aulacomya atra from the Beagle Channel (Tierra del Fuego, Argentina). Our results show that A. atra presents an extended spawning period from late winter to spring when the lowest value of mantle-gonad index (MGI) and maximum number of spawned individuals were observed. The MGI in mature males increased as the energy density of the mantle-gonad (ED $\left.{ }_{M G}\right)$ decreased, indicating

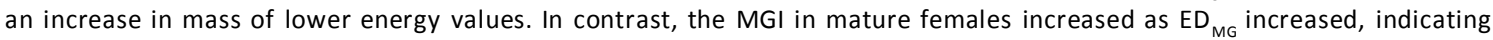
an increase in mass of higher energy values. Consequently, males and females reached a similar energy content of the mantle-gonad $\left(E C_{M G}\right)$ by means of different strategies: males have gonads of larger size but with lower energy by unit of mass than females. Besides, we observed a decrease in the digestive gland index (DGI) in concordance with an increase in the MGI of mature individuals, and a trend towards the depletion of ED and EC in the digestive gland during gonadal maturation. Our results evidence the role of the digestive gland as an energy reservoir and a different energy allocation strategy between sexes during gonadal maturation.
\end{abstract}

Key words: Energetics, calorimetry, reproduction, bivalve, Beagle Channel, Aulacomya atra

\section{INTRODUCTION}

In high-latitude marine environments, the strong seasonality observed in temperature and photoperiod influences food availability markedly (Clarke 1987). Consequently, accumulation of energy reserves in organisms can show temporal variations. The allocation of these reserves to different body components can provide relevant information on their functional roles and relative importance for the survival and reproduction of organisms (Chaparro \& Winter 1983, Lawrence \& McClintock 1994, Lucas 1996, Ahn et al. 2003, Pérez et al. 2010).

Food availability and temperature are considered the main factors affecting growth and reproduction of bivalves (MacDonald \& Thompson 1985a,b). Besides 
influencing energy balance, these variables affect the way in which available resources are allocated for the maintenance of the cellular machinery, growth, and reproduction (Iglesias \& Navarro 1991, Ahn et al. 2003, Barber \& Blake 2006). The reproductive cycle requires high inputs of energy, which can be supplied directly by ingested food, by reserves previously stored in different tissues, or by a combination of both strategies (Jayabal \& Kalyani 1986, Barber \& Blake 2006, Vite-García \& Saucedo 2008). The simultaneous study of the annual gametogenic cycle and the variation in energy content could give information about the specific pattern of energy storage and use (Morriconi et al. 2007).

Aulacomya atra (Molina 1782), commonly known as 'cholga' in Chile and Argentina and as 'Ribbed mussel' in South Africa, is a species distributed along the South American coasts; from southern Brazil to Tierra del Fuego on the Atlantic coast, and from the Beagle Channel to El Callao (Peru) on the Pacific coast (Castellanos 1967, Cancino \& Becerra 1978, Navarro \& Gutiérrez 1990¹, Zaixso 2004). A. atra is also found in South Africa (Griffiths 1977, Barkai \& Branch 1989). The Beagle Channel (Tierra del Fuego, Argentina) is the southernmost limit of the species distribution. The air temperature in the region is around $1.5^{\circ} \mathrm{C}$ in winter and $9^{\circ} \mathrm{C}$ in summer (Servicio Meteorológico Nacional 1986) ${ }^{2}$ and the surface water temperature ranges between $4.4^{\circ} \mathrm{C}$ in August and $9.4^{\circ} \mathrm{C}$ in January (Balestrini et al. 1998). Therefore, the gametogenesis and energy allocation of A. atra in Tierra del Fuego could be influenced by physiological restrictions related to the low temperatures of this region.

Aulacomya atra occurs from the intertidal zone up to $25 \mathrm{~m}$ depths in most of the beds surveyed in the Atlantic and Pacific waters (Gamarra \& Cornejo 2002, Zaixso 2004). In Tierra del Fuego, this species inhabits the lower level of the intertidal zone, and thus, individuals are exposed to the air only exceptionally during the low tides and for short periods of time.

Few studies have analyzed the gametogenesis and energy content of A. atra in South America. In Argentina, Vinuesa \& Tortorelli (1980) studied the reproductive cycle of this species, in populations from Puerto Deseado ( $47^{\circ} 44^{\prime}$ S). In Chile, the gonadal cycles and the effect of temperature and food availability on gamete maturation and spawning have been described for northern and southern populations (Jaramillo \& Navarro 1995, Avendaño \& Cantillánez 2012).

The objectives of this study were: a) to characterize gametogenesis in adult individuals of a population of Aulacomya atra located at the southernmost limit of its distribution; and b) to determine the allocation of energy to different organs, and its temporal variation in both males and females.

\section{Materials ANd Methods}

\section{STUdY SITE AND SAMPLING}

Specimens of Aulacomya atra were collected every 3-4 months from October 2009 to October 2010 in the intertidal rocky shore of Ensenada Zaratiegui (Tierra del Fuego National Park) Beagle Channel, Argentina (54 $51^{\prime}$ 'S, $68^{\circ} 29^{\prime}$ W; Fig. 1). To measure the seasonality of temperature throughout the year, one 1-wire Thermochron datalogger was deployed in the low edge of the mussel bed (mid-zone). This logger recorded air and water

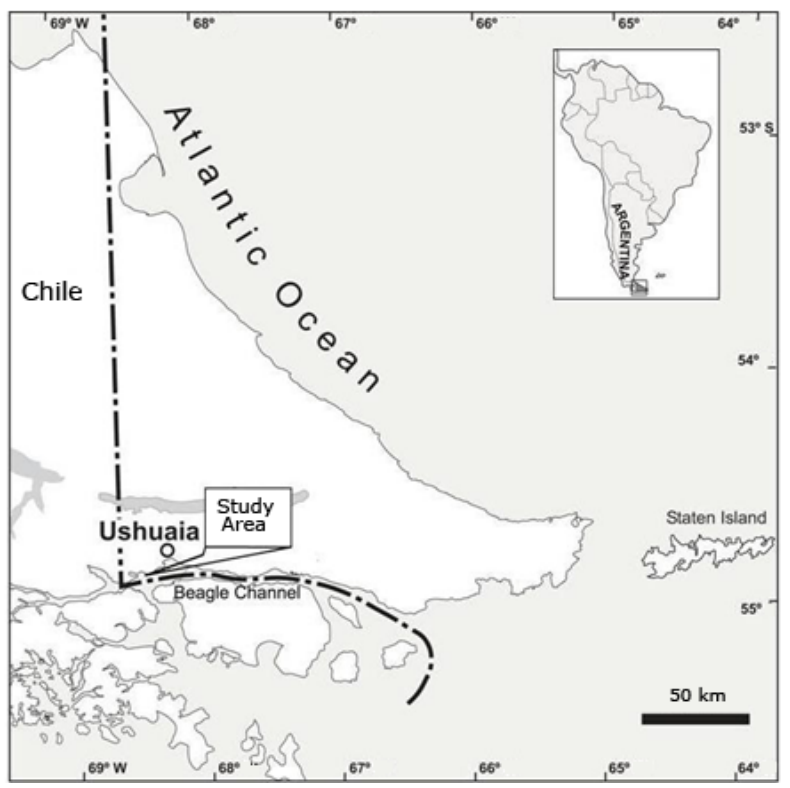

Figure 1. Sampling locality in Zaratiegui Embayment, Tierra del Fuego National Park, Tierra del Fuego, Argentina / Sitio de muestreo en Ensenada Zaratiegui, Parque Nacional Tierra del Fuego, Tierra del Fuego, Argentina

\footnotetext{
${ }^{1}$ Navarro JM \& A Gutiérrez. 1990. Sinopsis sobre el estado actual del cultivo de mitílidos en Chile. Cultivo de moluscos en Latinoamérica. Memorias de la Asociación Latinoamericana de Acuicultura, Segunda reunión de trabajo técnico, $189-210$ pp.

${ }^{2}$ Servicio Meteorológico Nacional. 1986. Estadísticas meteorológicas (1971-1980). Estadística № 36. Fuerza Aérea Argentina, Buenos Aires, $338 \mathrm{pp}$
} 
temperatures (depending on the tide level) every $1 \mathrm{~h}$ from October 2009 to October 2010. The monthly average day length was provided by the Servicio de Hidrografía Naval ${ }^{3}$. Individuals were transported to our laboratory and kept in sea water at $7^{\circ} \mathrm{C}$ for $24 \mathrm{~h}$.

\section{MaNTLE-GONAD AND DigeSTIVE GLAND INDEXES}

Shell length (maximum distance along the anterior posterior axis), width (maximum lateral axis) and height (dorsal/ventral axis) of each individual were measured to the nearest $0.01 \mathrm{~mm}$ using an electronic caliper, and total wet weight was recorded $(0.01 \mathrm{~g})$. The soft parts of the body were removed from the shells and weighed $( \pm 0.00001$ g). The mantle-gonad (MGI) and digestive gland (DGI) indexes were calculated for each individual as the ratio of organ wet mass ( $\mathrm{g}$ ) to total wet mass excluding the valves (g) multiplied by 100 .

\section{Histological analyses}

A cross-sectional mantle-gonad portion was removed from each specimen, fixed in Bouin's solution over $24 \mathrm{~h}$, washed with water and transferred to $70 \%$ alcohol. The portions were then dehydrated in an alcohol series, cleared in benzene, embedded in paraffin (Paraplast ${ }^{\circledR}$ ), sectioned at $5 \mu \mathrm{m}$ and stained with Groat's hematoxylin and eosin (Humason 1962).

\section{SEX DETERMination AND GaMETOGENIC STAGES}

The slides were examined microscopically, the sex was identified and, when suitable, each individual was assigned to one of 6 gametogenic stages: immature (I), growing $(\mathrm{G})$, mature $(\mathrm{M})$, spawned with recovery (SR), spawned with recovery and atresia (SRA), and spawned (S) (Figs. 3 and 4). These stages were defined based on standard gonadal scales for A. atra and other mollusks (Vinuesa \& Tortorelli 1980, Jaramillo \& Navarro 1995, Suárez et al. 2007, Oyarzún et al. 2011). Photomicrographs were taken with a digital camera attached to a Carl Zeiss ${ }^{\circledR}$ Axiostar microscope.

\section{Calorimetric determination}

Mantle-gonads and digestive glands were dried in an air circulating oven at $70^{\circ} \mathrm{C}$ to constant weight. After dry mass was obtained, samples were ground and pellets were made with a press (Parr, model $2812^{\circledR}$ ). The caloric contents of the pellets were measured in 30 individuals per season. The pellets (50-200 mg) were burned in a micro-bomb calorimeter (Parr, model $1425^{\circledR}$ ), up to complete combustion (Lucas 1996). The energy density of the mantle-gonads $\left(\mathrm{ED}_{\mathrm{MG}}\right)$ and digestive gland $\left(\mathrm{ED}_{\mathrm{DG}}\right)$ were calculated as $\mathrm{kJ} /$ g ash-free dry mass (Boy et al. 2009, Pérez et al. 2010). The total energy content of the mantle-gonads $\left(\mathrm{EC}_{\mathrm{MG}}\right)$ and digestive gland $\left(\mathrm{EC}_{\mathrm{DG}}\right)$ were calculated as the product between $\mathrm{ED}_{\mathrm{MG}}$ and $\mathrm{ED}_{\mathrm{DG}}$, and the total mass $(\mathrm{g})$ of the mantle-gonads or digestive gland respectively. The values obtained were corrected for ash and acid content. The micro-bomb calorimeter was periodically calibrated with benzoic acid.

Seasonal variations in MGI were analyzed using a oneway ANOVA, followed by Tukey HSD comparisons for an unbalanced design (Sokal and Rohlf 1995). Kendall Tau correlations were used to test for relationships between MGI and environmental variables such as photoperiod and water temperature (Zar 1984).

The sex ratio was analyzed with a Chi-square test, testing the hypothesis of a 1:1 male:female relation (Zar 1984). Sex could not be discriminated in the I stage, and the SRA and S stages were only found in females. Therefore, was performed a first analysis to test for significant differences in MGI and DGI between all gonadal stages without discriminating between sexes, by means of one-way ANOVAs. A two-way ANOVA was applied for each index (MGI and DGI) to test for significant differences between gonadal stages (G, M and SR) and sexes. Pairwise differences between gonadal stages were analyzed by unplanned Tukey HSD multiple comparisons for unequal N. When required, assumptions of normality (Kolmogorov-Smirnov test) and homogeneity of variances (Bartlett test) were previously verified (Sokal $\&$ Rohlf 1995). The same analyses were performed to study the variation in ED and EC both in mantle-gonads and digestive gland. $\mathrm{ED}_{\mathrm{DG}}$ and $\mathrm{EC}_{\mathrm{DG}}$ were transformed to $\mathrm{ED}_{\mathrm{DG}^{2}}$ and $\log \mathrm{EC}_{\mathrm{DG}}$ to meet the assumptions of the ANOVA model.

All statistical analyses were performed using the STATISTICA 6.0 Package (StatSoft Inc. 1998).

${ }^{3}$ Servicio de Hidrografía Naval de Argentina <http://www.hidro.gov.ar/observatorio/sol/asp> 


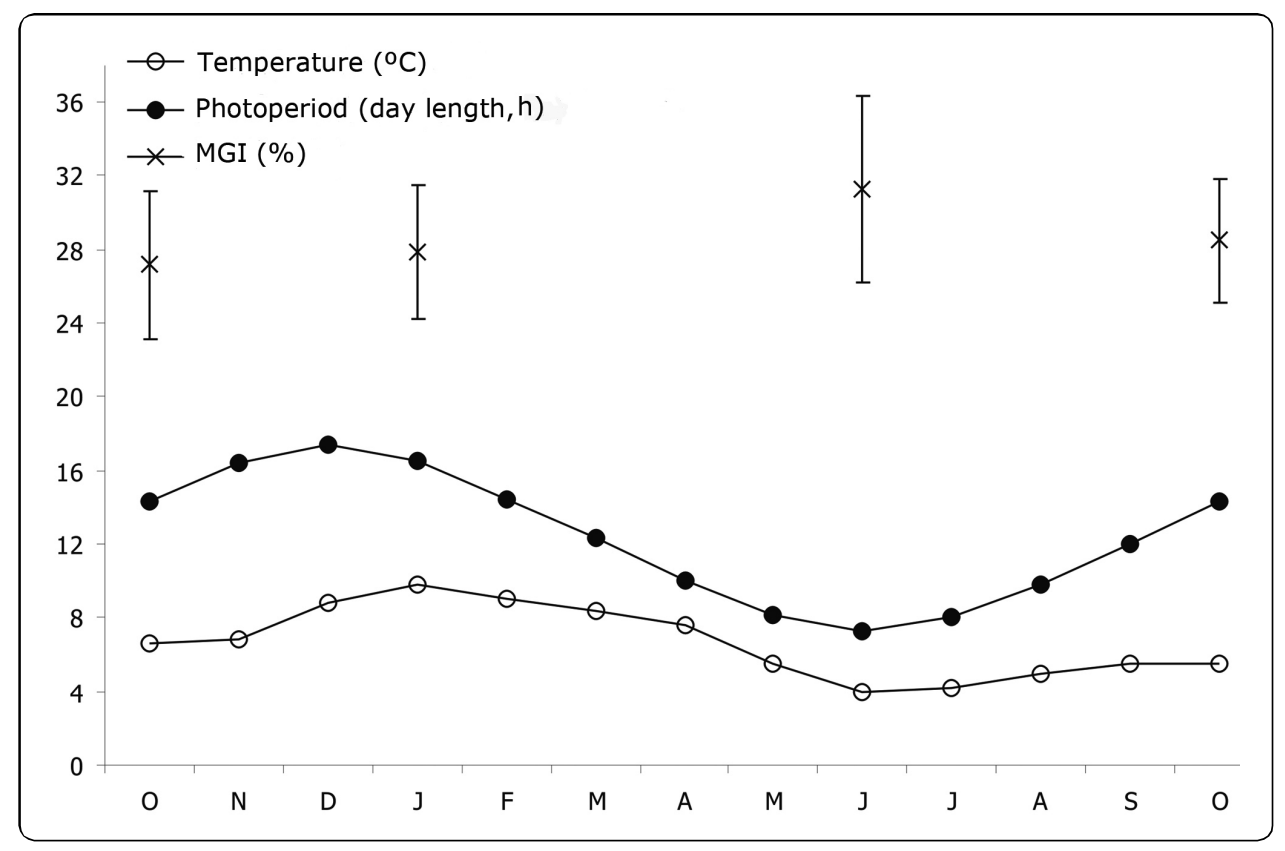

Figure 2. Mean mantle-gonad index (MGI \pm SD) for Aulacomya atra from the Beagle Channel (October 2009-0ctober 2010). M onthly means of seawater temperature and day length in the Beagle Channel / Índice gónada-manto promedio (MGI \pm DE) de Aulacomya atra del Canal Beagle (octubre 2009-octubre 2010). Promedios mensuales de la temperatura del agua y horas diarias de luz en el Canal Beagle

\section{RESULTS}

\section{SEX RATIO}

On each sampling, 35 adult specimens, from 51 to $73 \mathrm{~mm}$ in shell length, were randomly collected from the low edge of the mussel bed. A total of 65 males, 53 females, 1 hermaphrodite, and 8 immature individuals were determined during the histological analysis of the samples. Immature individuals were not considered for the sex ratio analysis. The sex ratio of the Beagle Channel population of $A$. atra studied did not differ significantly from a 1:1 proportion (Chi-square test: $\chi^{2}=0.55$, g.1. $=1, P=0.46$ ).

\section{TEMPERATURE, PHOTOPERIOD AND MANTLE-GONAD INDEX (MGI)}

During the study period, the mean temperature recorded was $4.4^{\circ} \mathrm{C}$ in winter and $9.2^{\circ} \mathrm{C}$ in summer and day lengths varied between $7.3 \mathrm{~h}$ in June and $17.4 \mathrm{~h}$ in December(Fig. 2).

The MGI was significantly different between seasons (one-way ANOVA $\mathrm{F}_{(3,122)}=5.83, P<0.001$, Fig. 2), being highest in June 2010 (Tukey HSD test for unequal N June 2010 vs. October 2009 and January 2010: $P<0.01$, June 2010 vs. October 2010: $P<0.05$ ). However, no correlation was observed between the MGI and water temperature or day length (Kendall Tau correlations $\tau=-0.67$, g.l. $=3, P=$ 0.17 and $\tau=-0.55$, g.l. $=3, P=0.26$ for temperature and photoperiod, respectively; Fig. 2).

\section{GAMETOGENIC STAGES AND REPRODUCTIVE CYCLE}

A total of 127 individuals were examined microscopically. The gonads of $A$. atra are located in the dorsal part of the visceral mass from which ventrally ramified tubules converge and open into the mantle cavity to release gametes into the sea water. Although this species is gonochoric, we found one hermaphrodite (1/127). Female mantle-gonads were brownish and granular, whereas male ones were light brown with a milky texture.

During summer, most individuals were in the growing stage $(\mathrm{G})$ (Figs. 3a, 4a, 5a, and 5b), and only $10 \%$ of the whole sample was immature. Germinal cells were present in the tubules in all developmental stages, but the number of mature ova and spermatozoa was low. At the end of autumn, most of the individuals were mature (M) (tubules were almost full of ripe gametes) (Figs. 3b, 4b, 5a and 5b), except $25 \%$ of males, which were partially spawned with recovery (SR), in which the presence of a spermatocyte and spermatid band indicated an imminent gonadal recovery (Fig. 5b). During spring, almost all males and most females were partially spawned with recovery (SR) 


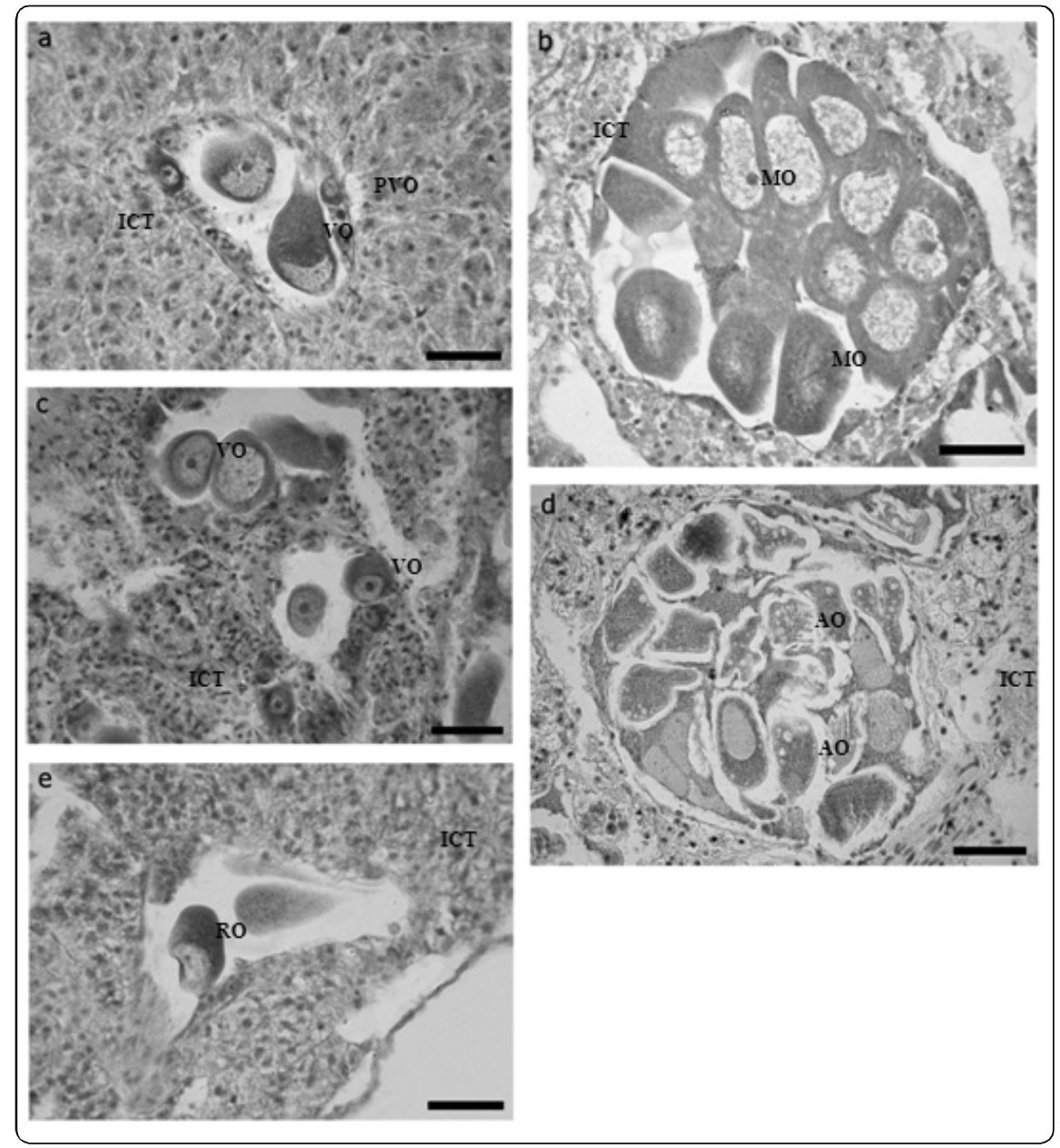

Figure 3. Histological sections of female gonads of A. atra from the Beagle Channel in different gametogenic stages: a) growing (G), b) mature (M), c) partially spawned with recovery (SR), d) partially spawned with recovery and atresia (SRA) and e) spawned (S). ICT: intertubular connective tissue, PVO: previtellogenic oocytes, VO: vitellogenic oocytes, MO: mature oocytes, AO: atresic oocytes, RO: relict ovas. Scale bar $50 \mu \mathrm{m} /$ Secciones histológicas de gónadas femeninas de A. atra del Canal Beagle en diferentes estadíos gametogénicos (G), b) maduro (M), c) parcialmente desovado con recuperación (SR), d) parcialmente desovado con recuperación y atresia (SRA) y e) desovado (S). ICT: tejido conectivo intertubular, PVO: oocitos pre vitelogénicos, VO: oocitos vitelogénicos, MO: oocitos maduros, AO: oocitos atrésicos, RO: ovas relictuales. Barra $50 \mu \mathrm{m}$

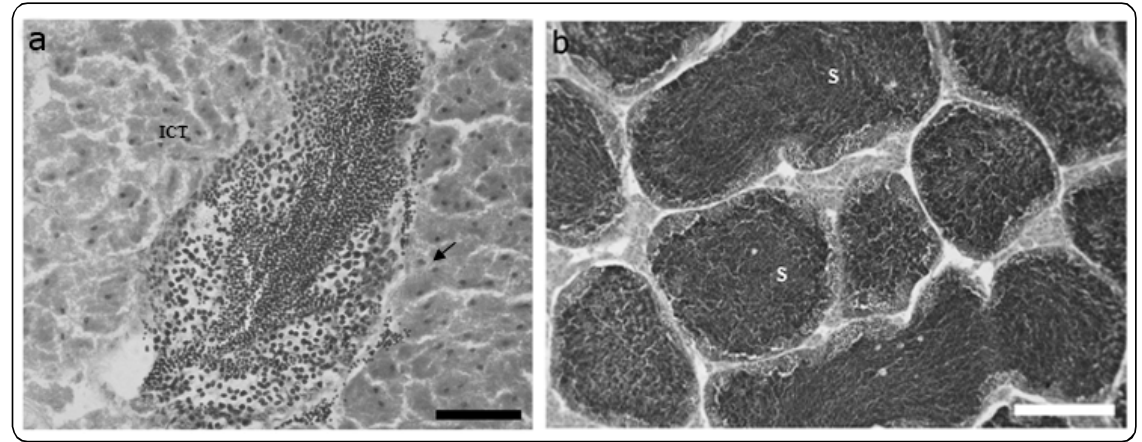

Figure 4. Histological sections of male gonads of A. atra from the Beagle Channel in different gametogenic stages: a) growing (G) and b) mature (M). ICT: intertubular connective tissue, Arrow: developing germinal layer, S: spermatozoa. Scale bar $\mathbf{5 0} \mu \mathrm{m} /$ Secciones histológicas de gónadas masculinas de $A$. atra del Canal Beagle en diferentes estadíos gametogénicos: a crecimiento $(G)$ y b maduro (M). ICT: tejido conectivo intertubular, Flecha: capa germinal en desarrollo, S: espermatozoides. Barra $50 \mu \mathrm{m}$ 


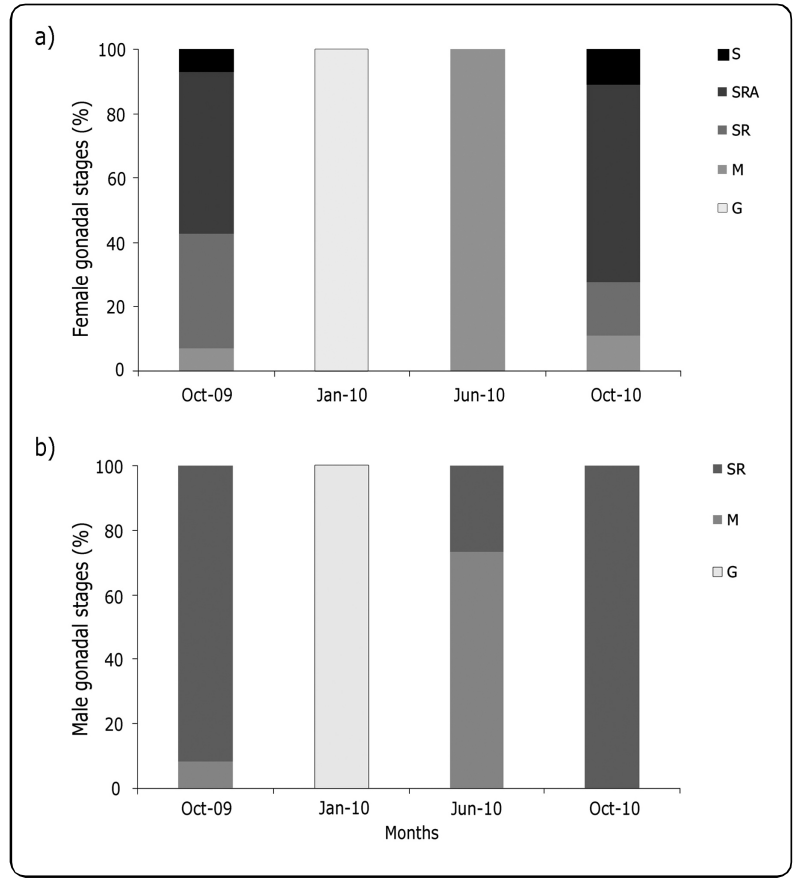

Figure 5. Seasonal changes in the percentage of females (a) and males (b) of $A$. atra in the different gametogenic stages ( $G$ growing, $M$ mature, SR spawned and recovery, SRA spawned and recovery with atresia, and S spawned) between October 2009 and October 2010 / Cambios estacionales en el porcentaje de hembras (a) y machos (b) de A. atra en diferentes estadíos de maduración gonadal ( $G$ en maduración, $M$ maduro, $S R$ desovado con recuperación, SRA desovado con recuperación y atresia) entre octubre 2009 y octubre 2010

(Figs. 3c, 5a and 5b), with an increased percentage of females with signs of follicular atresia (SRA) (Figs. 3d and 5a). Atresia and degeneration of gametes during spawning, followed by recovery, were recorded. In spermatozoa, lysis is not as evident as in oocytes, since the former have virtually no cytoplasm. The remaining spring females $(\sim 10 \%)$ were either mature $(\mathrm{M})$, or spawned (S) (Figs. 3e and 5a).

\section{MANTLE-GONAD INDEX (MGI), DIGESTIVE GLAND INDEX (DGI) AND GONADAL STAGES}

When analyzing overall MGI and DGI (not discriminating between sexes), we found that values varied significantly among gonadal stages (ANOVA $\mathrm{F}_{(5,117)}=3.62, P<0.01$ and $\mathrm{F}_{(5,117)}=5.16, P<0.001$, for MGI and DGI, respectively). Individuals in the $\mathrm{M}$ stage had a significantly higher MGI than those in the SRA stage (Fig. 6a), and a significantly lower DGI than those in the G, SR and SRA stages (Fig. 6b). When only the G, M and SR stages were compared, significant differences in MGI were observed between stages and sexes $\left(\right.$ ANOVA $_{(2,88)}=6.09, P<0.01, \mathrm{~F}_{(1,88)}=$

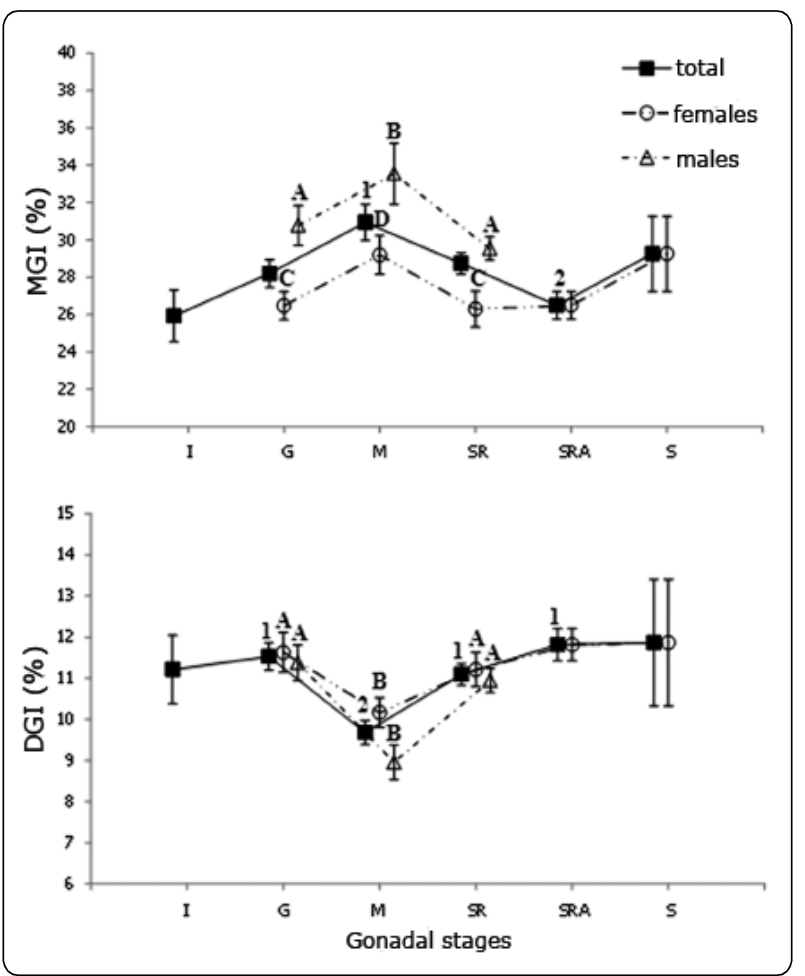

Figure 6. Mean mantle-gonad index (a, MGI) and digestive gland index (b, DGI) of $A$. atra for each gonadal stage (I immature, G growing, M mature, SR spawned and recovery, SRA spawned and recovery with atresia, $S$ spawned). Error bars show standard error of mean MGI and DGI values. Significant differences in indexes are indicated by different numbers for comparisons between all gonadal stages without discriminating between sexes and different letters for comparisons between gonadal stages and sexes / Índice gónada-manto promedio (a, MGI) e índice de la glándula digestiva (b, DGI) de A. atra para cada estadío de maduración gonadal (I inmaduro, $G$ en maduración, $M$ maduro, $S R$ desovado con recuperación, SRA desovado con recuperación y atresia, S desovado). Las barras de error indican el error estándar respecto de los valores de MGI y DGI promedio. Las diferencias significativas son indicadas con números distintos para comparaciones entre todos los estadíos sin discriminar sexos y con letras distintas para las comparaciones entre estadíos y sexos

$20.35, P<0.01$ and $\mathrm{F}_{(2,88)}=0.17, P=0.84$, for stage, sex and interaction, respectively). The MGI was higher in males than in females for all stages, and individuals in the $\mathrm{M}$ stage had a significantly higher MGI than those in the $G$ and SR stages for both sexes (Fig. 6a).

The DGI showed significant differences between gonadal stages (ANOVA $\mathrm{F}_{(2,88)}=11.2, P<0.001$ ), but not between sexes $\left(\mathrm{F}_{(1,88)}=2.55, P=0.11\right)$. The interaction between both factors was not significant for the DGI $\left(\mathrm{F}_{(2,88)}=0.82, P=0.45\right)$. Animals in the $\mathrm{M}$ stage had a 


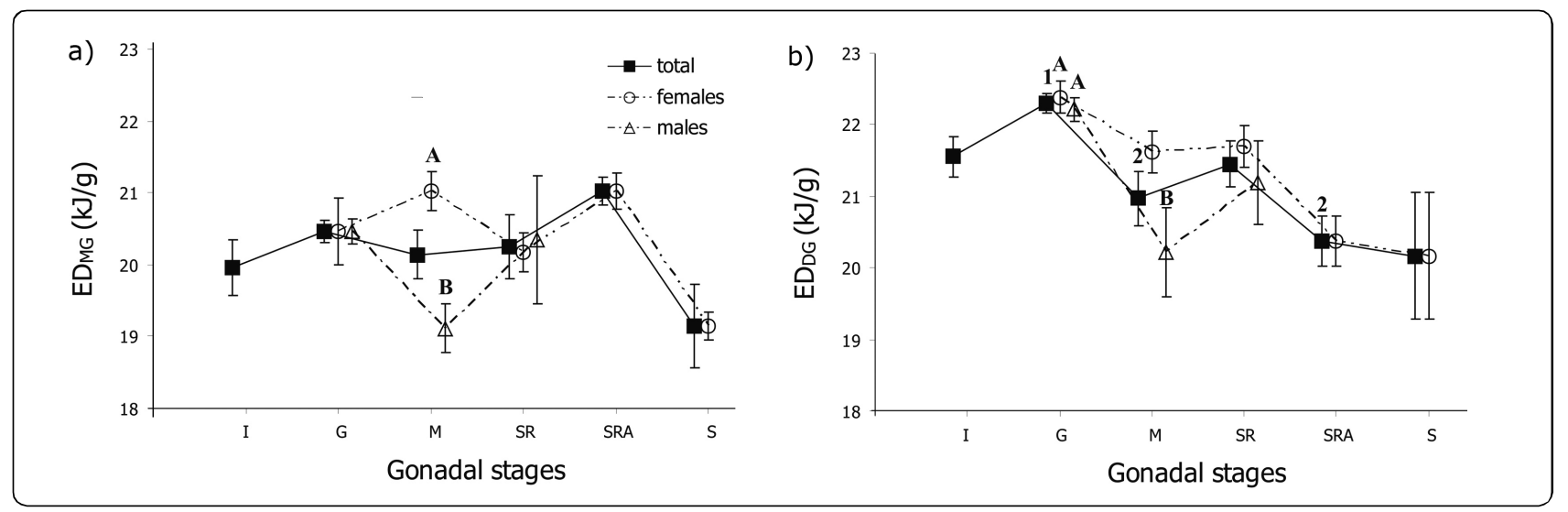

Figure 7. Mean energy density of the mantle-gonad $\left(a, E D_{M G}\right)$ and digestive gland $\left(b, E D_{D G}\right)$ of $A$. atra for each gonadal stage $(I$ immature, $G$ growing, M mature, SR spawned and recovery, SRA spawned and recovery with atresia, S spawned). Error bars show standard error of mean ED values. Significant differences in indexes are indicated by different numbers for comparisons between all gonadal stages without discriminating between sexes and different letters for comparisons between gonadal stages and sexes / Densidad energética promedio del manto-gónada $\left(a, \mathrm{ED}_{\mathrm{MG}}\right)$ y de la glándula digestiva $\left(\mathrm{b}, \mathrm{ED}_{\mathrm{DG}}\right)$ de $\mathrm{A}$. atra para cada estadío de maduración gonadal ( $\mathrm{inmaduro,} \mathrm{G}$ en maduración, $\mathrm{M}$ maduro, SR desovado con recuperación, SRA desovado con recuperación y atresia, S desovado). Las barras de error indican el error estándar respecto de los valores de ED promedio. Las diferencias significativas son indicadas con números distintos para comparaciones entre todos los estadíos sin discriminar sexos y con letras distintas para las comparaciones entre estadíos y sexos

significantly lower DGI than those in the other two stages (Fig. 6b).

$$
\begin{aligned}
& \text { ENERGY DENSITY OF MANTLE-GONADS ( } \text { ED }_{\text {MG }} \text { ) AND } \\
& \text { DIGESTIVE GLAND (ED } \text { DG } \text { ) }
\end{aligned}
$$

$\mathrm{ED}_{\mathrm{MG}}$ did not vary significantly among gonadal stages when analyzed without discriminating between sexes

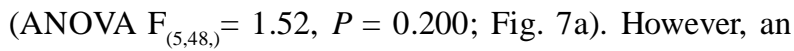
interaction between sexes and stages was observed when the $\mathrm{ED}_{\mathrm{MG}}$ of the $\mathrm{G}, \mathrm{M}$, and $\mathrm{SR}$ stages was compared (ANOVA $\mathrm{F}_{(2,31)}=3.66, P<0.05$ ). The $\mathrm{ED}_{\mathrm{MG}}$ was lower in mature males than in mature females (Fig. 7a).

Moreover, significant differences among gonadal stages were found for $\mathrm{ED}_{\mathrm{DG}^{2}}$ (ANOVA $_{(5,48)}=4.91, P<$ 0.001, Fig. 7b). Individuals in the $G$ stage had higher ED than those in the M and SRA stages (Fig. 7b). Analysis of the $\mathrm{ED}_{\mathrm{DG}^{2}}$ of the $\mathrm{G}, \mathrm{M}$, and $\mathrm{SR}$ stages showed significant differences between stages and sexes (ANOVA $\mathrm{F}_{(2,31)}=$ 6.33, $P<0.01, \mathrm{~F}_{(1,31)}=4.42, P<0.05$ and $\mathrm{F}_{(2,31)}=1.20, P=$ 0.3164 , for stage, sex and interaction, respectively). The $\mathrm{ED}_{\mathrm{DG}^{2}}$ values of mature males were lower than those of individuals in the growing stage (Fig. 7b).

\section{ENERgy CONTENT OF MANTLE-gonads $\left(\mathrm{EC}_{\mathrm{MG}}\right)$ AND DIGESTIVE GLAND $\left(\right.$ EC $\left._{\text {DG }}\right)$}

When analyzing overall $\mathrm{EC}_{\mathrm{MG}}$ (not discriminating between sexes), we found that values varied significantly among gonadal stages (ANOVA $\mathrm{F}_{(5,48)}=10.08, P<0.001$ ).
Individuals in the $\mathrm{G}$ and $\mathrm{M}$ stages had higher energy content than those in the I and SR stages (Fig. 8a). When only the G, M and SR stages were compared, significant differences in $\mathrm{EC}_{\mathrm{MG}}$ were observed between stages (ANOVA $_{(2,31)}=17.39, P<0.001, \mathrm{~F}_{(1,31)}=0.5583, P>0.05$ and $\mathrm{F}_{(2,31)}=3.25 P=0.052$, for stages, sex and interaction, respectively). Animals in the $\mathrm{SR}$ stage had lower $\mathrm{EC}_{\mathrm{MG}}$ than those in the $G$ and $M$ stages for both sexes (Fig. 8a).

The energy content of the digestive gland $\left(\log \mathrm{EC}_{\mathrm{DG}}\right)$ differed among gonadal stages (ANOVA $\mathrm{F}_{(5,48)}=3.23, P<$ 0.05 ), although post-hoc comparisons were unable to show significant differences (Fig. 8a). Furthermore, when the $\log \mathrm{EC}_{\mathrm{DG}}$ of G, M and SR was analyzed, no interaction was observed between gonadal stage and sex (ANOVA $\mathrm{F}_{(2,31)}=$ 2.36, $P=0.111)$ and significant differences were observed between stages $\left(\mathrm{F}_{(2,31)}=6.72, P<0.01\right)$ but not between sexes $\left(F_{(1,31)}=0.63, P=0.434\right)$. Males in the $G$ stage had higher $\log \mathrm{EC}_{\mathrm{DG}}$ than mature males and than males in the SR stage (Fig. 8b).

\section{Discussion}

Our results show that the Aulacomya atra population living in the intertidal zone of the Beagle Channel has an extended spawning period from late winter to spring, when the lowest value of MGI and the maximum number of spawned (SR, SRA and S) individuals were observed (Figs. 2 and 5). MGI increased until winter, reaching its maximum in June (the coldest and darkest month) (Fig. 2). Variation patterns of MGI (Fig. 6a) were similar in both 

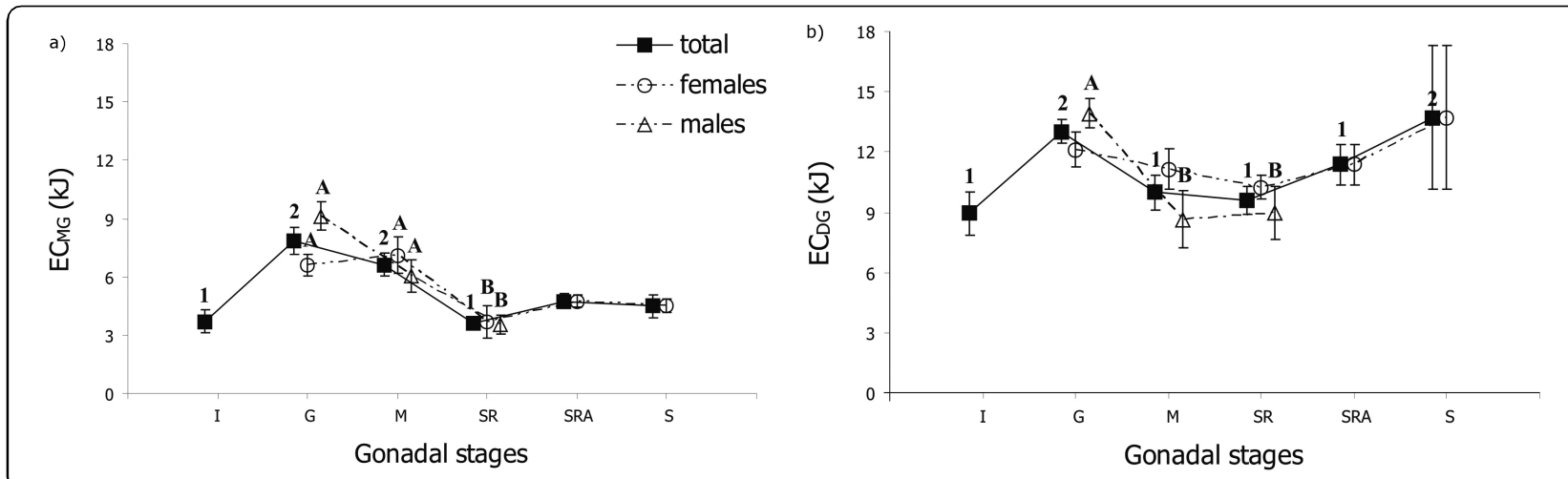

Figure 8. Mean energy content of the mantle-gonad $\left(\mathrm{a}, \mathrm{EC}_{\mathrm{mc}}\right)$ and digestive gland $\left(\mathrm{b}, \mathrm{EC} \mathrm{C}_{\mathrm{d}}\right)$ of $\mathrm{A}$. atra for each gonadal stage (I immature, $\mathrm{G}$ growing, M mature, SR spawned and recovery, SRA spawned and recovery with atresia, and S spawned). Error bars show standard error of mean EC values. Significant differences in indexes are indicated by different numbers for comparisons between all gonadal stages without discriminating between sexes and different letters for comparisons between gonadal stages and sexes / Contenido energético promedio del manto-gónada $\left(\mathrm{a}, \mathrm{EC}_{\mathrm{MG}}\right)$ y de la glándula digestiva $\left(\mathrm{b}, \mathrm{EC}_{\mathrm{DG}}\right)$ de $\mathrm{A}$. atra para cada estadío de maduración gonadal (I inmaduro, $\mathrm{G}$ en maduración, M maduro, SR desovado con recuperación, SRA desovado con recuperación y atresia, S desovado). Las barras de error indican la desviación estándar respecto de los valores de EC promedio

sexes, as found for a Chilean population of A. atra (Jaramillo \& Navarro 1995), Anodonta gabillotia pseudodopsis (Sereflisan et al. 2009) and Mytilus chilensis (Oyarzún et al. 2011).

Environmental conditions, especially temperature, photoperiod, and food availability, influence gamete maturation and spawning of marine invertebrates (Griffiths 1977, Lawrence \& Soame 2004, Santos et al. 2011). Even though no correlation was observed between MGI and temperature or photoperiod in the time period studied, a trend was observed. The highest MGI (mature stage) values occurred in early June, when day length was shortest and water temperature was lowest. Subsequently, MGI decreased in coincidence with the increase in day length and water temperature. In October, when day length was 13-14 h, most of the individuals were found in gonadal recovery and spawned stages, coincident with the increase in primary production (Almandoz et al. 2011).

Similar results were found by Tortorelli (1987) in a nearby locality. The population studied by Tortorelli reached gonadal maturity in winter and then had an extended period of spawning (from the end of winter until summer), which was associated with the decrease in sea water temperature. Influence of seasonality on spawning of A. atra was also found by other authors in populations

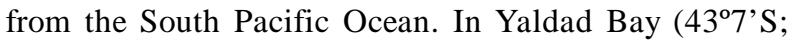
$73^{\circ} 43^{\prime}$ W), Jaramillo \& Navarro (1995) observed periods of greater spawning intensity in April, August-November and February, and reported that food availability was the most important factor for successful development of gametogenesis and spawning. In Caleta Punta Arenas

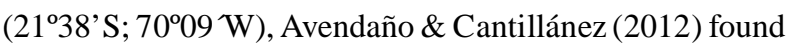
continuous spawning throughout the year, with 2 important peaks during August-September and OctoberNovember, associated with a decrease in water temperature. In a population of Puerto Deseado, in the South Atlantic Ocean $\left(47^{\circ} 45^{\prime} \mathrm{S}\right.$; $\left.65^{\circ} 55^{\prime} \mathrm{W}\right)$, Vinuesa and Tortorelli (1980) reported 2 spawning periods (January and April) but found no relationship with sea water temperature. The spawning period of the southernmost population of A. atra studied here seems not to differ from the general pattern described for other populations of this species, and seems to be associated with the increase in water temperature after winter and probably also with primary productivity.

Oocyte degradation and atresia have been observed in other mytilids, namely Mytilus edulis (Pipe 1987) and Mytilus galloprovincialis (Suárez et al. 2007). In M. galloprovincialis, Suárez et al. found that atresia and degradation of gametes are more intense during winter and infrequent in spring, when the main spawning occurs, and that non-favorable environmental conditions could explain the occurrence of this phenomenon (Suárez et al. 2007). Besides, Paulet $e$ t al. (1988) found that temperature may act as a cue in Pecten maximus and that spawning takes place only if water temperature reaches $15.5-16^{\circ} \mathrm{C}$, and that otherwise, pronounced atresia occurs in mature gonads. Although the regulating mechanism of oocyte atresia is not well known, some factors such as low temperature, nutritional deficit (Galap et al. 2004) and environmental pollution (Steele \& Mulcahy 1999) could be involved. We found atresia in A. atra during spring, coinciding with the 
spawning period, and only in females, although it likely occurs in males as well. Degradation and atresia in male gametes are difficult to detect because spermatozoa have a very small amount of cytoplasm (Suárez et al. 2007).

We found evidences that the high energy demands of gonadal maturation are supplied at least by the intertubular connective tissue of gonads and by the digestive gland. The histology and cellular organization of reproductive tissues in A. atra showed that the intertubular connective tissue and gonadal tubules present an inverse growth cycle (Figs. 3 and 4), as previously reported for other populations of this species (Vinuesa \& Tortorelli 1980, Jaramillo \& Navarro 1995), and for other bivalves in general (Gosling 2003, Oyarzún et al. 2011). Gonadal tubules showed their maximum development during sexual maturity when intertubular tissue was minimal. Several authors have suggested that intertubular tissue provides the energy needed during gametogenesis in bivalves. Mytilus edulis females (and maybe also males), for example, accumulate reserves in the mantle off the gonadal cells (Gabbott \& Peek 1991). In the present study, we observed a decrease in DGI in concordance with the increase in MGI in mature individuals (Fig. 6) and a trend towards the depletion of ED and EC of the digestive gland during gonadal maturation, i.e. from growing individuals to mature ones (Figs. $7 \mathrm{~b}$ and $8 \mathrm{~b}$ ), although it was significant only for males. These findings suggest the translocation of energy from the digestive gland to the gonads during gonadal maturation in A. atra.

In the population under study, energy allocation differed between sexes. Mature females allocated more energy per unit organ to mantle-gonads than mature males (Fig. 7a) since sperm cells require less energy than oocytes to complete maturation. After maturity, the $\mathrm{ED}_{\mathrm{MG}}$ of males and females converged to similar values, and decreased abruptly at spawning (Fig. 7a). We also found that males and females reached similar $\mathrm{EC}_{\mathrm{MG}}$ (Fig. 8a) values by means of different strategies: males had gonads of larger size (Fig. 6a) but with lower energy by unit of mass (energy density) than females (Fig. 7a) (sperm cells have less reserve substances than oocytes) (Pérez et al. 2010). With the beginning of the spawning period, a sharp decrease in MGI occurred given by the decrease in the mass of mantle-gonads in relation to the whole mass of the individual. Summarizing, the increase in MGI in mature males occurred together with a decrease in $\mathrm{ED}_{\mathrm{MG}}$ (indicating an increase in mass of lower energy values), whereas the increase in MGI in mature females occurred together with an increase in mass of higher energy values, such as vitellum (Pérez et al. 2010), which increased ED $_{\mathrm{MG} \text {. }}$

Several authors have studied patterns of storage and ultimate utilization of energy reserves in mussels by measuring proximal composition, which is an indirect method (Gabbott 1975, Zandee et al. 1980, Hawkins et al. 1985). In contrast, the present study is the first to study energy allocation patterns in ribbed mussels through direct calorimetric determinations. Our results evidenced the role of the connective tissue of gonads and the digestive gland as energy reservoirs for gonadal maturation in A. atra of the Beagle Channel, and a different energy allocation strategy between sexes during gonadal maturation. Given that our results refer to individuals of A. atra living in the intertidal area of the southern limit of the species distribution, and considering the results on other bivalve species, which have shown differences in relative energy invested in reproduction among intertidal individuals as well as differences in reproductive cycles and gonad indexes between intertidal and subtidal populations (Alfaro et al. 2003, Petes et al. 2008), studies implementing calorimetric determinations in subtidal individuals from the same locality are needed. Moreover, studies of energy allocation to gametogenesis are needed on other populations of $A$. atra along its wide distribution. This will help us understand the plasticity in the lifehistory of the species.

\section{LITERATURE CITED}

Ahn IY, J Surh, YG Park, H Kwon, KS Choi, SH Kang, HJ Choi, KW Kim \& H Chung. 2003. Growth and seasonal energetics of the Antarctic bivalve Laternula elliptica from King George Island, Antarctica. Marine Ecology Progress Series 257: 99-110.

Alfaro AC, AG Jeffs \& SH Hooker. 2003. Spatial variability in reproductive behaviour of green-lipped mussel populations of northern New Zealand. Molluscan Research 23: 223-238.

Almandoz GO, MP Hernando, GA Ferreyra, IR Schloss \& ME Ferrario. 2011. Seasonal phytoplankton dynamics in extreme southern South America (Beagle Channel, Argentina). Journal of Sea Research 66: 47-57.

Avendaño M \& M Cantillánez. 2012. Reproductive cycle, collection and early growth of Aulacomya ater, Molina 1782 (Bivalvia: Mytilidae) in northern Chile. Aquaculture Research 44(9): 1327-1338.

Balestrini CF, G Manzella \& GA Lovrich. 1998. Simulación de corrientes en el Canal Beagle y Bahía Ushuaia, mediante un modelo bidimensional. Servicio de Hidrografía Naval 98: $1-58$. 
Barber BJ \& NJ Blake. 2006. Reproductive physiology. In: Shumway SE \& GJ Parsons (eds). Scallops: biology, ecology, and aquaculture, pp. 357-416. Elsevier, Netherlands.

Barkai A \& GM Branch. 1989. Growth and mortality of the mussels Choromytilus meridionalis (Krauss) and Aulacomya ater (Molina) as indicators of biotic conditions. Journal of Molluscan Studies 55: 329-342.

Boy CC, AF Pérez, DA Fernández, J Calvo \& ER Morriconi. 2009. Energy allocation in relation to spawning and overwintering of a diadromous Puyen (Galaxias maculatus) population in the southernmost limit of the species distribution. Polar Biology 32(1): 9-14.

Castellanos ZA. 1967. Catálogo de los moluscos marinos bonaerenses, 365 pp. Anales de la Comisión Científica, Provincia de Buenos Aires, La Plata.

Cancino J \& R Becerra. 1978. Antecedentes sobre la biología y tecnología del cultivo de Aulacomya ater (Molina, 1782), (Mollusca: Mytilidae). Biología Pesquera 10: 27-45.

Chaparro OR \& JE Winter. 1983. The effect of winter period, gametogenesis and spawning on the calorific content of soft parts in Mytilus chilensis. Aquaculture 32: 419-422.

Clarke A. 1987. Temperature, latitude and reproductive effort. Marine Ecology Progress Series 38: 89-99.

Coe WR. 1943a. Sexual differentiation in mollusks. I. Pelecypods. Quarterly Review of Biology 18: 154-164.

Coe WR. 1943b. Development of the primary gonads and differentiation of sexuality in Teredo navalis and other pelecypod mollusks. The Biological Bulletin 84: 178-186.

Coe WR. 1945. Development of the reproductive system and variations in sexuality in Pecten and other pelecypod molluscs. Transactions of the Connecticut Academy of Arts and Sciences 36: 673-700.

Gabbott P. 1975. Storage cycles in marine bivalve molluscs: a hypothesis concerning the relationship between glycogen metabolism and gametogenesis. In: Barnes H (ed). Proceedings 9th European Marine Biology Symposium 191211 pp. Aberdeen University Press, Aberdeen.

Gabbott P \& K Peek. 1991. Cellular biochemistry of the mantle tissue of the mussel Mytilus edulis L. Aquaculture 94: 165176.

Galap C, F Leboulenger \& JP Grillot. 2004. Seasonal variations in biochemical constituents during the reproductive cycle of the female dog cockle Glycymeris glycymeris. Marine Biology 129: 625-634.

Gamarra A \& O Cornejo. 2002. Study of the Mussel Aulacomya ater, Molina, 1782 (Bivalvia: Mytilidae), near Santa Rosa Island, Independence Bay, Peru, during the El Niño Phenomenon 1997-98. Investigaciones Marinas 30(1): 140-140.

Gosling E. 2003. Bivalve mollusks. Biology, ecology and culture, 443 pp. Blackwell Science, Oxford.
Griffiths RJ. 1977. Reproductive cycles in littoral populations of Choromytilus meridionalis (Kr.) and Aulacomya ater (Molina) with a quantitative assessment of gamete production in the former. Journal of Experimental Marine Biology and Ecology 30: 53-71.

Hawkins AS, PN Salkeld, BL Bayne, E Gnaiger \& DM Lowe. 1985. Feeding and resource allocation in the mussel Mytilus edulis: evidence for time-averaged optimization. Marine Ecology Progress Series 20: 273-287.

Humason GL. 1962. Animal tissue techniques, 468 pp. WH Freeman and Company, San Francisco.

Iglesias JIP \& E Navarro. 1991. Energetics of growth and reproduction in cockles (Cevastoderma edule): seasonal and age-dependent variations. Marine Biology 111: 359-368.

Jaramillo JR \& JM Navarro. 1995. Reproductive cycle of the Chilean ribbed mussel Aulacomya ater (Molina, 1782). Journal of Shellfish Research 14(1): 165-171.

Jayabal R \& M Kalyani. 1986. Biochemical studies in the hard clam Meretrix meretrix (L) from Vellar Estuary, East Coast of India. Indian Journal of Marine Science 15: 63-64.

Langston WJ, GR Burt \& BS Chesman. 2007. Feminization of male clams Scrobicularia plana from estuaries in Southwest UK and its induction by endocrine disrupting chemicals. Marine Ecology Progress Series 333: 173-84.

Lawrence JM \& JB McClintock. 1994. Energetic acquisition and allocation by echinoderms (Echinodermata) in polar seas: adaptations for success? In: David B, A Guille, J Feral \& M Roux (eds). Echinoderms through time, pp. 39-52. Balkema Press, Rotterdam.

Lawrence AJ \& JN Soame. 2004. The effects of climate change on the reproduction of coastal invertebrates. Ibis 146: 29-39.

Lucas A. 1996. Energetics of aquatic animals, 169 pp. Taylor and Francis, London.

MacDonald BA \& RJ Thompson. 1985a. Influence of temperature and food availability on the ecological energetics of the giant scallop Placopecten magellanicus. I. Growth rates of shell and somatic tissue. Marine Ecology Progress Series 25: 279-294.

MacDonald BA \& RJ Thompson. 1985b. Influence of temperature and food availability on the ecological energetics of the giant scallop Placopecten magellanicus. II. Reproductive output and total production. Marine Ecology Progress Series 25: 295-303.

Montenegro VD, PA Olivares \& MT González. 2010. Hermaphroditism in marine mussel Perumytilus purpuratus (Lamarck, 1819) (Mollusca: Mytilidae). International Journal of Morphology 28(2): 569-573.

Morriconi E, B Lomovasky \& J Calvo. 2007. Reproductive cycle and energy content of Tawera gayi (Hupé 1854) (Bivalvia: Veneridae) at the southernmost limit of their distribution range. Journal of Shellfish Research 26(1): 81-88. 
Ortiz-Zarragoitia M \& MP Cajaraville. 2010. Intersex and oocyte atresia in a mussel population from the Biosphere's Reserve of Urdaibai (Bay of Biscay). Ecotoxicology and Environmental Safety 73(5): 693-701.

Oyarzín P, J Toro, R Jaramillo, R Guiñez, C Briones \& M Astorga. 2011. Ciclo gonadal del chorito Mytilus chilensis (Bivalvia: Mytilidae) en dos localidades del sur de Chile. Latin American Journal of Aquatic Research 39(3): 512-525.

Paulet YM, A Lucas \& A Gerard. 1998. Reproduction and larval development in two Pecten maximus (L.) populations from Brittany. Journal of Experimental Marine Biology and Ecology 119: 145-156.

Pérez AF, CC Boy, ER Morriconi \& J Calvo. 2010. Reproductive cycle and reproductive output of the sea urchin Loxechinus albus (Echinodermata: Echinoidea) from Beagle Channel, Tierra del Fuego, Argentina. Polar Biology 33(3): 271-280.

Petes LE, BA Menge \& AL Harris. 2008. Intertidal mussels exhibit energetic trade-off between reproduction and stress resistance. Ecological Monographs 78(3): 387-402.

Pipe RK. 1987. Oogenesis in the marine mussel Mytilus edulis: an ultrastructural study. Marine Biology 95: 405-414.

Santos S, JF Cardoso, C Carvalho, PC Luttikhuizen \& HW Van der Veer. 2011. Seasonal variability in somatic and reproductive investment of the bivalve Scrobicularia plana (da Costa, 1778) along a latitudinal gradient. Estuarine, Coastal and Shelf Science 92: 19-26.

Sereflisan H, S Cek \& M Sereflisan. 2009. Histological studies on gametogenesis, hermaphroditism and the gametogenic cycle of Anodonta gabillotia pseudodopsis (Locard, 1883) in the Lake Golbasi, Turkey (Bivalvia: Unionidae). Journal of Shellfish Research 28(2): 337-344.

Sokal RR \& FJ Rohlf. 1995. Biometry: the principles and practice of statistics in biological research, $887 \mathrm{pp}$. Freeman, New York.
Steele S \& MF Mulcahy. 1999. Gametogenesis of the oyster Crassostrea gigas in southern Ireland. Journal of the Marine Biological Association of the United Kingdom 79: 673-686.

Suárez P, C Álvarez, P Molist \& F San Juan. 2007. Atresia gonadal durante el ciclo gametogénico de Mytilus galloprovincialis Lamarck, 1819 cultivado en la ría de Vigo (noroeste de la península Ibérica). Boletín, Instituto Español de Oceanografía 23(1-4): 3-10.

Tortorelli MC. 1987. Contribución al estudio de los ciclos reproductivos del mejillón patagónico Mytilus chilensis Hupé y de la cholga Aulacomya ater (Molina) en el Canal Beagle. $\mathrm{PhD}$ Thesis, Universidad de Buenos Aires, Buenos Aires, $257 \mathrm{pp}$.

Vinuesa JH. 1977. Sobre un caso de hermafroditismo en la cholga Aulacomya ater (Molina). Physis 37: 63-65.

Vinuesa JH \& MC Tortorelli. 1980. Ciclo sexual de la cholga, Aulacomya ater (Molina) en Puerto Deseado. Physis 39(86): 21-32.

Vite-García N \& PE Saucedo. 2008. Energy storage and allocation during reproduction of pacific pearl oyster Pteria sterna at Bahía de La Paz, Baja California Sur, Mexico. Journal of Shellfish Research 27(2): 375-383.

Zaixso HE. 2004. Bancos de cholga Aulacomya atra atra (Molina) (Bivalvia: Mytilidae) del golfo San José (Chubut, Argentina): Diversidad y relaciones con facies afines. Revista de Biología Marina y Oceanografía 39(2): 61-78.

Zandee DI, JH Kluytmans, W Zurburg \& H Pieters. 1980. Seasonal variations in biochemical composition of Mytilus edulis with reference to energy metabolism and gametogenesis. Netherlands Journal of Sea Research 14: 1-29.

Zar JH. 1984. Biostatistical analysis, 718 pp. Prentice-Hall, Englewood Cliffs. 